\title{
Late-glacial Coleoptera fauna from Lismore, Nova Scotia
}

\author{
Randall F. Miller \\ Natural Sciences Division, New Brunswick Museum, Saint John, New Brunswick E2K 1E5, Canada \\ and \\ Alan V. Morgan \\ Quaternary Sciences Institute, Department of Earth Sciences, University of Waterloo, \\ Waterloo, Ontario N2L 3G1, Canada
}

Date Received October 15, 1991

Date Accepted November 20, 1991

\begin{abstract}
Fossil Coleoptera from a late-glacial site near Lismore, Nova Scotia record paleoclimatic and paleoecological conditions prior to the Younger Dryas in eastern Canada. A buried peat deposit dated 11,900 years B.P. near the base and 10,500 years B.P. at the top contains a small insect fauna that includes both boreal species, such as $O$ lophrum consimile, and subarctic beetle species like Elaphrus lapponicus. Although a palynological study of the Lismore site shows evidence of the Younger Dryas, the beetle fauna is poorly preserved in sandy peat deposits dated younger than 10,600 years B.P.
\end{abstract}

Les coléoptères fossiles provenant d'une site tardi-glaciaire près de Lismore, Nouvelle-Écosse, témoignent des conditions paléoclimatiques et paléoécologiques antérieures au Dryas tardif de l'est du Canada. Un dépôt de tourbe, datant de 11,900 B.P. à la base et de 10,500 B.P. au sommet, contient une faune de petits insectes qui inclut autant des espèces boréales, comme Olophrum consimile, que des espèces subarctiques, telle Elaphrus lapponicus. Bien que l'étude palynologique du site de Lismore montre des évidences du Dryas tardif, la faune de coléoptères est mal préservée dans les dépôts de tourbière sablonneux plus jeunes que 10,600 B.P.

[Traduit par le journal]

\section{INTRODUCTION}

Over the past decade a number of papers have discussed the late-glacial environment of Atlantic Canada, especially in relation to the Younger Dryas event. Mott et al. (1986) and Stea and Mott (1989) summarized information gathered from a number of buried organic sites in New Brunswick and Nova Scotia and provided stratigraphic interpretation, radiocarbon chronology and pollen records that have been used to piece together a picture of deglaciated environments from about 14,000 to 10,000 years B.P. The work has resulted in a detailed analysis of deglaciated environments and evidence for active glaciers of Younger Dryas age in Nova Scotia.

Many of the buried organic sites, especially those detailed by Stea and Mott (1989), are suitable for paleoentomological analysis and have been shown to contain variously preserved insect assemblages composed largely of beetle remains (Miller, 1989; Stea and Mott, 1990; Miller and Morgan, 1991). This paper examines the Coleoptera fauna of the Lismore site. Related sites are under investigation with the intention of completing a paleoentomological survey of a wide range of late-glacial buried organic sites in the Maritimes.

\section{Location and Stratigraphy}

The Lismore site is located along the Northumberland Strait shore $10 \mathrm{~km}$ southwest of Arisaig $45^{\circ} 41^{\prime} 48^{\prime \prime N}$; $62^{\circ} 17^{\circ} 40^{\prime \prime} \mathrm{W}$ (Fig. 1). At the section, Silurian sandstone is overlain by $2 \mathrm{~m}$ of red medium sand to fine gravel, up to 40 $\mathrm{cm}$ of fibrous peat and 50 to $150 \mathrm{~cm}$ of red sand with silty clay seams. Radiocarbon dates are $11,900 \pm 100$ years B.P. (GSC$4153)$ at the base of the peat and $10,500 \pm 120$ years B.P. (GSC-4156) at the top. The upper half of the peat is very sandy with a distinct break dated at 10,600 \pm 100 years B.P. (GSC-4762) (Stea and Mott, 1989).

\section{Coleoptera Fauna}

A total of $68 \mathrm{~kg}$ of peat and sandy peat, taken at $5 \mathrm{~cm}$ intervals from section A (Fig. 1), was submitted to standard paleoentomological analysis (Morgan, 1988). An additional $13.4 \mathrm{~kg}$ of peat, equivalent to the 0 to $15 \mathrm{~cm}$ interval at section $A$, was taken as a bulk sample from section $B$ about $60 \mathrm{~m}$ west of section A. Identified samples were mounted on micropaleontology slides and are stored at the New Brunswick Museum. Preservation was good although the actual number of 


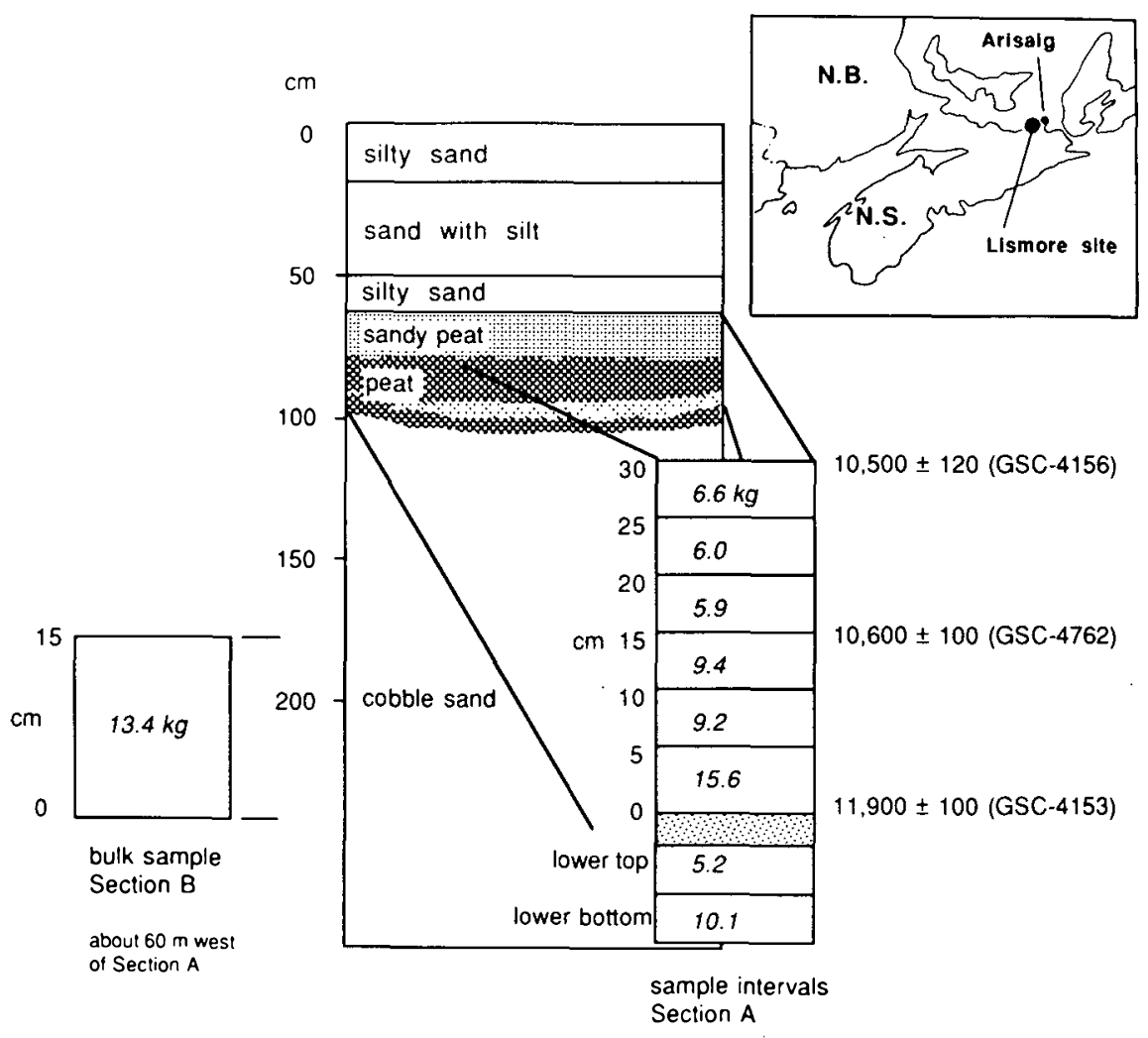

Fig. 1. Location of Lismore and stratigraphy of site.

specimens was low. The richest samples for beetle analysis were found in the lower $15 \mathrm{~cm}$ of the sections where the peat contains little sand. In the sandy upper half of section A, the number of beetle specimens drops dramatically providing very little information. The transition to sandy peat has been radiocarbon dated at about 10,600 years B.P. (Fig. 1).

The taxonomic list (Table 1) from Lismore indicates that species of staphylinid (rove beetles) were most abundant. Total numbers of individuals were also highest for this group of beetles. The fossils identified to the species level include Acidota quadrata (Campbell, 1982), Olophrum consimile, Olophrum rotundicolle (Campbell, 1983) and Tachinus tachyporoides (Campbell, 1973). Other staphylinid beetles included relatively large numbers of Stenus spp., and Eucnecosum brunnescens / tenue (Campbell, 1984) and several specimens of Gymnusa cf. campbelli / konopackii / smetanai (Klimaszewski, 1979). All these beetles are typical of riparian habitats, either living in Carex or Sphagnum bogs, under leaf litter or on sandy shores of standing or slow moving water. Most of the species identified above are typical of the boreal forest while some may occur adjacent to the northern treeline or in alpine tundra habitats. Their presence at Lismore indicates conditions cooler than present. Other beetle species listed in Table 1 are generally indicative of riparian habitats, most living in moss or on aquatic vegetation.

The most common carabids or ground beetles were Dyschirius spp. along with Bembidion. Specimens of cf. Pterostichus and Elaphrus were also present. Among the ground beetles at least one species, Elaphrus lapponicus, has a more northern distribution.

One specimen of scolytid or bark beetle was present in the "lower-top" level of section A (Fig. 1). Phloeotribus piceae is an inhabitant of spruce trees.

\section{Description of Selected Species}

Elaphrus lapponicus lives in subarctic regions and in North America is found from Alaska to Labrador and at higher altitude or "colder" sites in northern Quebec, Ontario, Gaspe and Alberta (Fig. 2a) (Lindroth, 1961; Goulet, 1983; Morgan, 1989). Adults are hygrophilous and live near cold water. Specimens taken at the northern limit of trees on the Koroc River (Nouveau Québec) were in an area well-vegetated with short gaminoid plants in a grove of Alnus, Salix, Larix and Picea (Morgan, 1989).

Acidota quadrata has been collected from Alnus, Salix and other kinds of deciduous leaf litter near streams, under rocks at edges of snowfields and from wet moss and in leaf detritus near streams in alpine tundra (Campbell, 1982). It is a widely distributed, northern Holarctic species (Fig. 2b). In North America, A. quadrata is known from arctic and alpine zones and northerly areas of the boreal forest. It ranges from Alaska and Northwest Territories to Labrador, and south at higher elevations to British Columbia and northern Montana with relict populations in Colorado, New Hampshire and Maine. It was found in association with E. lapponicus on the Koroc River (Morgan, unpublished). 
Table 1. Taxonomic list of Coleoptera from the Lismore site. Figures represent minimum number of specimens per level.

Section A

Section B

$\begin{array}{lllllllllllll}\text { Taxa } & \text { Level \# } & 1 & 2 & 3 & 4 & 5 & 6 & 7 & 8 & & \text { Bulk }\end{array}$

Carabidax

Bembidion spp.

Dyschirius spp.

Elaphrus lapponicus

cf. Pterostichus spp.

genera indet.

genera indet. a

genera indet. $b$

$\begin{array}{lll}5 & 3 & 2 \\ 2 & 2 & 1 \\ 4 & & \end{array}$

\section{Dytiscidae}

genera indet.

genera indet. a

genera indet. $b$.

2

4

Hydrophilidae

Helophorus spp.

Hydraenidae

genera indet.

cf. Hydraena spp.

1

12

Leiodidae

Agathidium spp.

Staphylinidae

Acidota cf. quadrata

Acidota spp.

cf. Acidota

Anotylus/Oxytelus sp.

cf. Bledius

Eucnecosum brunnescens / tenue

cf. Eucnecosum

Gymnusa

Olophrum consimile

Olophrum rotundicolle

Olophrum cf. rotundicolle

Olophrum spp.

cf. Philonthus/Quedius

Stenus spp.

Tachinus cf. tachyporoides

Tachinus sp.

Aleocharinae

Pselaphidae

genera indet.

Scarabaeidae

genera indet.

Bynthidae

Cytilus cf. alternatus

Curculionidae

genera indet. a

genera indet. $b$

genera indet. c

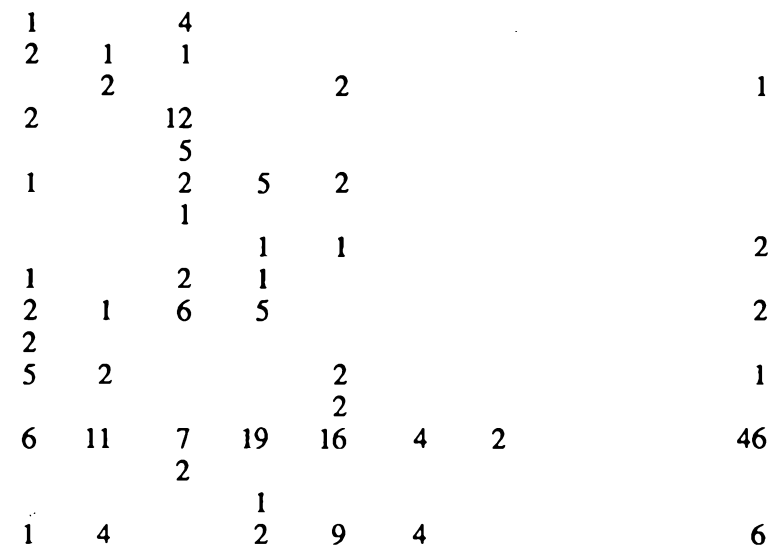

Chysomelidae

genera indet.

Donacia/Plateumaris spp.

Scolytidae

Phloeotribus piceae

$1=$ lower $/$ bottom; $2=$ lower $/$ top; $3=0-5 \mathrm{~cm} ; 4=5-10 \mathrm{~cm} ; 5=10-15 \mathrm{~cm} ; 6=15-20 \mathrm{~cm} ; 7=20-25 \mathrm{~cm} ; 8=25-30 \mathrm{~cm}$ Bulk = bulk sample, Section B 


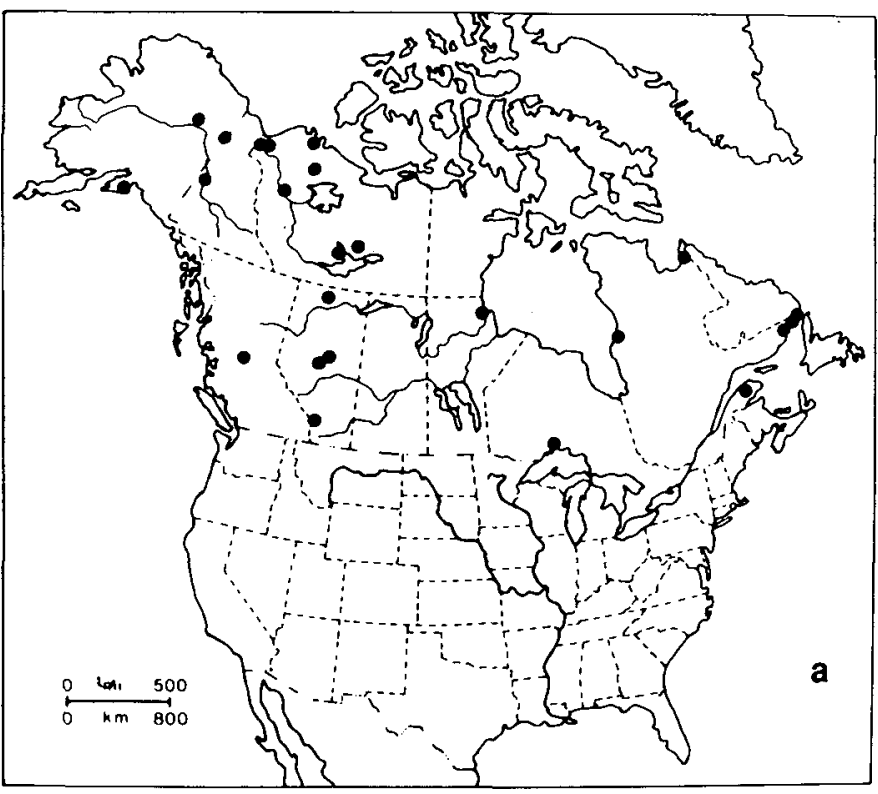

Fig. 2a. Modern distribution of Elaphrus lapponicus (O).

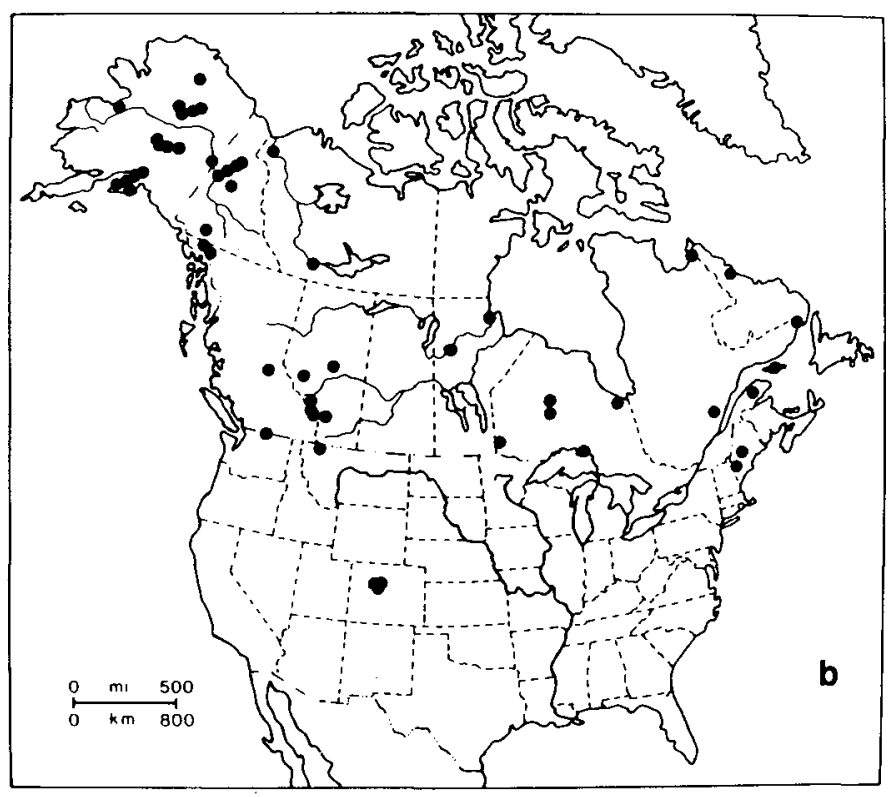

Fig. 2b. Modern distribution of Acidota quadrata (O).
Gymnusa cf. campbelli / konopackii / smetanai are all similar northern species found in wet moss or swampy areas on the shores of shallow lakes (Klimaszewski, 1979). G. smetanai has been collected from tundra habitats. It is a boreal Holarctic species, widely distributed across Canada (Fig. 2c). G. campbelli is described as a northern species known from Alaska, Northwest Territories and Newfoundland. G. konopackii is a northern species known only from Alaska.

Phloeotribus piceae inhabits trees of the genus Picea spp. (Bright, 1976). This is a widely distributed transcontinental beetle whose distribution generally follows the boreal forest region.

\section{Discussion}

Stratigraphic and palynological data compiled from 14 sites in eastern Canada led Mott et al. (1986) to describe a widespread climatic oscillation equivalent in time to the Allerød / Younger Dryas in Europe. Their evidence is seen in both lake sediments and in late-glacial buried organic sites. Stea and Mott (1989) discussed the genesis of sediments overlying the organic beds as being of key significance to the interpretation of late-glacial events in Nova Scotia. They recognized fluvial gravel and sand, lacustrine sand, silt and clay and diamictons at various sites and related these deposits to possible readvances of ice during the Younger Dryas. Sediments overlying the peat at Lismore were interpreted as ponded sediments from a lake or floodplain, most likely lacustrine or glaciolacustrine in origin. Unlike other sites they describe, such as Collins Pond, there is no direct evidence of Younger Dryas glaciation at Lismore.

Sedge pollen is dominant throughout at Lismore, declining somewhat near the transition from peat to sandy peat at the $15 \mathrm{~cm}$ level in section $A$. In the lower half $(0$ to $15 \mathrm{~cm}$, section A and section B) birch and spruce increase to a maximum at the contact with the sandy peat. Spruce is attributed to long-distance transport with no evidence of trees growing at the site. In the sandy peat, birch and spruce decline abruptly and sedge, willow, alder and grasses increase. The decrease in spruce pollen was interpreted as a possible deforestation of spruce (Stea and Mott, 1989).

The beetle species identified from the Lismore section are typical of the modern boreal forest, and most have northern boreal or subarctic affinities. Few would be found in the area of Lismore today. The beetle fauna indicates conditions cooler than present and is generally consistent with the interpretations based on studies of pollen. One of the beetle species identified from Lismore, Phloeotribus piceae, indicates the presence of trees. This would contradict the palynological interpretation which found no evidence for trees at the site. While none of the other species directly indicate the presence of trees, neither might they be considered strictly tundra or open ground species. Interestingly, practically all of the identified species $E$. lapponicus, A. quadrata, $O$. rotundicolle, $O$. consimile and $E$. brunnescens / tenue were all collected together at the northern edge of trees on the Koroc River in northern Quebec. The mean July temperature for this area is close to $11^{\circ} \mathrm{C}$ (Morgan, 1989) while at Lismore it is about $18^{\circ} \mathrm{C}$ (Anonymous, 1974). In the more sandy upper part of the section beetle fossils become less common and only a very few fragments were recovered from the upper 5 $\mathrm{cm}$ level. Whether this reflects cooling conditions or changing local habitat is uncertain. Based on the radiocarbon chronology, the upper 15 to $20 \mathrm{~cm}$ of sandy peat was deposited in only 100 years, compared to almost 1,300 years for the lower $15 \mathrm{~cm}$ of peat. The sparse beetle fauna in the upper part of the section might relate to the relatively rapid deposition. 


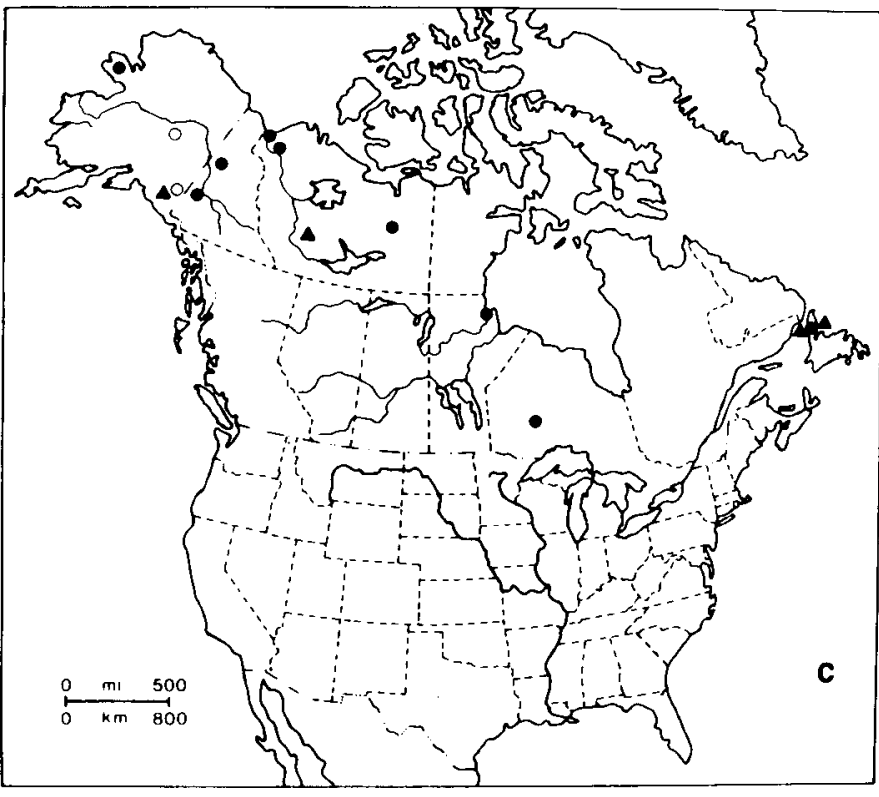

Fig. 2c. Modern distribution of Gymnusa campbelli ( $\Delta) /$ konopackii (O) / smetanai (O).

Coope (1977) discussed the changes in Coleoptera fauna during the Younger Dryas or Loch Lomond stadial in Britain. Sites dating between 11,000 and 10,000 years B.P. include a large number of boreal or boreomontane species suggesting a cooling during this period. Certainly there is no indication of an invasion of "cold" species at Lismore or the disappearance of boreal species in favour of those considered strictly subarctic as observed in British sites. Only by examining beetle fossils from a number of sites will we be able to build of picture of the late-glacial Coleoptera fauna in the Maritimes. The exact timing of the Younger Dryas event in Nova Scotia remains a question, although one might expect that at Lismore the changing sedimentation might be indicative of a climatic change. If this is true, the poor preservation of beetles in the sandy peat younger than about 10,600 years B.P. would not help to record such an event.

\section{ACKNOWLEDGements}

Thanks are extended to R.J. Mott (Geological Survey of Canada) and R.R. Stea (Nova Scotia Department of Mines and Energy) for their assistance and encouragement. S. Bedell and J. Pilny provided valuable technical assistance in sample preparation. Our appreciation also goes to A. Capson for helping to develop preparation lab facilities at the NBM.

Anonymous. 1974. The Climate of Canada. Department of Transport, Meteorlogical Branch, Air Services, Toronto, 74 p.
Bright, D.E. 1976. The Insects and Arachnids of Canada, Part 2. The Bark Beetles of Canada and Alaska. Coleoptera: Scolytidae. Canada Department of Agriculture, Publication 1576, Ottawa, 241 p.

Campbell, J.M. 1973. A revision of the genus Tachinus (Coleoptera: Staphylinidae) of North and Central America. Entomological Society of Canada, Memoir 90, 137 p.

1982. A revision of the North American Omaliinae (Coleoptera: Staphylinidae), the genus Acidota Stephens. Canadian Entomologist, 114, pp. 1003-1029.

1983. A revision of the North American Omaliinae (Coleoptera: Staphylinidae), the genus Olophrum Erichson. Canadian Entomologist, 115, pp. 577-622.

1984. A revision of the North American Omaliinae (Coleoptera: Staphylinidae), the genera Arpedium Erichson and Eucnecosum Reitter. Canadian Entomologist, 116, pp. 487527.

Coope, G.R. 1977. Fossil Coleoptera assemblages as sensitive indicators of climatic changes during the Devensian (Last) cold stage. Philosophical Transactions of the Royal Society of London, 280, pp. 313-340.

Goulet, H. 1983. The genera of Holarctic Elaphrini and species of Elaphrus Fabricius (Coleoptera: Carabidae): classification, phylogeny and zoogeography. Quaestiones Entomologicae, 19, pp. 219-482.

Klimaszews Ki, J. 1979. A revision of the Gymnusini and Deinopsini of the world. Coleoptera: Staphylinidae, Aleocharinae. Monograph No. 25, Agriculture Canada, 169 p.

Lindroth, C.H. 1961. The ground beetles of Canada and Alaska, 2. Opuscula Entomologica, Supplementum 20, pp. 1-200.

Miller, R.F. 1989. Fossil Coleoptera studies of Late-Glacial sites in Nova Scotia. Atlantic Geology, 25, p. 165.

Miller, R.F. and Morgan, A.V. 1991. Fossil Coleoptera from Lismore, Nova Scotia: Life before the Younger Dryas. Programme and Abstracts 1991, CANQUA, p. 28.

Morgan, A.V. 1988. Late Pleistocene and Early Holocene Coleoptera in the Lower Great Lakes Region. In Late Pleistocene and Early Holocene Paleoecology and Archaeology of the Eastern Great Lakes Region. Edited by R.S. Laub, N.G. Miller, and D.W. Steadman. Bulletin of the Buffalo Society of Natural Sciences, 33, pp. 195-206.

1989. Coleoptera along Eastern Ungava Bay, Québec: Part 1, Carabidae. Le Naturaliste Canadien (Revue d'ecologie et de systematique), 116, pp. 27-34.

Mott, R.J., Grant, D.R., Stea, R.R., and Occhietti, S. 1986. Late-glacial climatic oscillation in Atlantic Canada equivalent to the Allerød-Younger Dryas event. Nature, 323, pp. 247-250.

SteA, R.R. and Mott, R.J. 1989. Deglaciation environments and evidence for glaciers of Younger Dryas age in Nova Scotia, Canada. Boreas, 18, pp. 169-187.

1990. Quaternary Geology of Nova Scotia; Guidebook for 53rd Annual Friends of the Pleistocene Field Excursion. Nova Scotia Department of Mines and Energy, Open File Report 90-008, 85 p. 